\author{
J. C. Möller \\ G. Nachtrodt \\ L. Gortner
}

\section{Vancomycin intoxications in preterm infants}

Received: 27 August 1993

Accepted: 22 September 1993

Tissing et al. [7] reported a case of reversible acute renal failure in a preterm infant under vancomycin treatment. They used however a dosage regimen which is no longer appropriate for preterm infants [6]. Several recently published controlled clinical studies demonstrated that a vancomycin dosage as low as $12 \mathrm{mg} / \mathrm{kg}$ per day does achieve therapeutic peak levels and trough levels above the minimal inhibitory concentration [1-3].

In our own studies, $10 \mathrm{mg} / \mathrm{kg}$ per day used to prevent coagulase-negative staphylococcal septicaemia still led to vancomycin peak levels above $10 \mu \mathrm{g} / \mathrm{l}$ (bactericidal concentrations) and trough levels above the minimal inhibitory concentration in $95 \%$ of 120 very low birth weight infants $[4,5]$. The average creatinine levels were $62 \mu \mathrm{mol} / 1( \pm 17 \mathrm{SD})$ on day 3 of treatment. Urine output and blood pressure did not change significantly. Creatinine levels on day 6 and after vancomycin treatment were not significantly different from levels on day 3 . We believe a much lower dosage of vancomycin than that reported by Tissing et al. is adequate to prevent and treat coagulase-negative staphylococcal septicaemia. Vancomycin doses should be adjusted to post-conceptional age, birth-weight and pre-treatment creatinine levels [5]. With that approach toxic symptoms are extremely unlikely.

\section{References}

1. James A, Koren G, Milliken J, Soldin S Prober C (1987) Vancomycin pharmacokinetics in infants: relationship to postconceptional age and serum creatinine. Dev Pharmacol Ther 14:77-83

2. Koren G, James A (1987) Vancomycin dosing in preterm infants: prospective verification of new recommendations. J Pediatr 110:797-798

3. Leonard MB, Koren G, Stevenson DK, Prober C (1989) Vancomycin pharmacokinetics in very low birth weight infants and in very low birth weight neonates. Pediatr Infect Dis J 8:282286
4. Möller JC, Nachtrodt $G$, Richter A, Tegtmeyer FK (1992) Prophylactic vancomycin in prevent staphylococcal septicaemia in very-low-birth-weightinfants. Lancet 340:424

5. Möller JC, Nachtrodt G, Richter A, Tegtmeyer FK, Gortner L (1993) Pharmacology of prophylactic low-dose vancomycin in very low-birth-weight infants. Dev Pharmacol Ther 19:178182

6. Schaad UB, McCracken GH, Nelson JD (1980) Clinical pharmacology and efficacy of vancomycin in pediatric patients. J Pediatr 96: 119-126

7. Tissing EJE, Umans-Eckenhausen MAW, Anker JN van den (1993) Vancomycin intoxication in a preterm infant. Eur J Pediatr 152:700

\section{J. C. Möller (凶) · G. Nachtrodt}

L. Gortner

Department of Paediatrics,

Medical University of Lübeck,

Kahlhorststrasse 31-35,

D-23538 Lübeck, Germany

\section{W. J. E. Tissing}

J. N. van den Anker

\section{Reply}

Received, accepted: 22 September 1993

Sir: Dr. Möller et al. comment that our regimen of vancomycin treatment (a daily dose of $30 \mathrm{mg} / \mathrm{kg}$ divided into two doses) [4] is not appropriate for preterm infants anymore. They furthermore suggest that several recently published clinical studies demonstrated that appropriate peak and trough levels of vancomycin are reached after a vancomycin dosage as low as 12 $\mathrm{mg} / \mathrm{kg}$ per day $[1,3]$. We disagree with the comments of Möller et al. Koren et al $[2,3]$ recommend a daily regimen of 36 $\mathrm{mg} / \mathrm{kg}$ divided into two doses in patients with a postconceptional age between 31 and 36 weeks and a body weight between 1200 and $2000 \mathrm{~g}$. We would like to emphasise that our patient had a birth weight above $1500 \mathrm{~g}$, a postconceptional age of 33 weeks and a serum creatinine of 41 $\mu \mathrm{mol} / 1(0.46 \mathrm{mg} / \mathrm{dl})$. Kildoo et al. [2] recommended that for patients over 2 weeks of age and with a postconceptional age over 30 weeks, the serum creatinine should be used to determine the appropriate initial dosing regimen. A daily dose of $30 \mathrm{mg} / \mathrm{kg}$ is recommended for patients with a serum creatinine $<53 \mu \mathrm{mol} / 1(0.6$ $\mathrm{mg} / \mathrm{dl}$ ). Therefore, after using the serum creatinine and postconceptional age as our guide we therefore treated our patient accordingly.

We would like to stress that despite proper dosing based on postconceptional age and glomerular filtration rate, serum level monitoring is obligatory because of the wide interindividual variability and rapid changes in renal function.

\section{References}

1. James A, Koren G, Milliken J, Soldin S, Prober C (1987) Vancomycin pharmacokinetics in infants: relationship to postconceptional age and serum creatinine. Dev Pharmacol Ther 14:77-83

2. Kildoo CW, Lin LM, Gabriel MH, Folli HL, Modanlou HD (1990) Vancomycin pharmacokinetics in infants: relationship to postconceptional age and serum creatinine. Dev Pharmacol Ther 14:7783

3. Koren G, James A (1987) Vancomycin dosing in preterm infants: prospective verification of new recommendations. J Pediatr 110:797-798

4. Tissing WJE, Umans-Eckenhausen MAW, Anker JN van den (1993) Vancomycin intoxication in a preterm in fants. Eur J Pediatr 152:700

W. J. E. Tissing (凶) - J. N. van den Anker Department of Paediatrics, Division of Neonatology, Erasmus University and University Hospital Rotterdam. Sophia Children's Hospital, Gordelweg 160, 3038 GE Rotterdam. The Netherlands 